Portland State University

PDXScholar

\title{
Understanding the Drivers of Forest, Residential, and Agricultural Land Values in Yamhill County Using Hedonic Models
}

\author{
Emily D. Dietrich \\ Portland State University
}

Follow this and additional works at: https://pdxscholar.library.pdx.edu/mem_gradprojects

Part of the Environmental Monitoring Commons

Let us know how access to this document benefits you.

\section{Recommended Citation}

Dietrich, Emily D., "Understanding the Drivers of Forest, Residential, and Agricultural Land Values in Yamhill County Using Hedonic Models" (2013). Environmental Science and Management Professional Master's Project Reports. 26.

https://pdxscholar.library.pdx.edu/mem_gradprojects/26

https://doi.org/10.15760/mem.14

This Project is brought to you for free and open access. It has been accepted for inclusion in Environmental Science and Management Professional Master's Project Reports by an authorized administrator of PDXScholar. Please contact us if we can make this document more accessible: pdxscholar@pdx.edu. 
Understanding the drivers of forest, residential, and agricultural land values in Yamhill County using hedonic models

by

\author{
Emily D. Dietrich
}

A report submitted in partial fulfillment of the requirements for the degree of Masters of Environmental Management

Project Committee:

David Ervin

Heejun Chang

Dennis Yee

The Department of Environmental Science and Management

Portland State University

2013 
This research was partially supported by the US National Science Foundation under grant No. 1026629. Views expressed in this material are the authors' and do not necessarily reflect those of the sponsoring agencies.

\section{Abstract}

Hedonic modeling is commonly used in land and property value estimations in an attempt to identify the impact that various attributes have on the market value of that property. The purpose of this study is to examine the factors contributing to land value of agricultural, forest, and residential properties in Yamhill County, as part of the Spatial Ecosystem Services Analysis, Modeling, and Evaluation (SESAME, http://www.pdx.edu/ecosystem-services/) project. This paper discusses the process and preliminary results of the development of hedonic models that will be utilized for predicting land value changes under future land conversion scenarios. Applying the models to future scenarios will provide insight into the effect that land conversion will have on market value of land in Yamhill County, in order to elucidate one component of the total land value in the area. Numerous studies have performed hedonic modeling in order to provide greater understanding of the non-market ecosystem service values that are contributing to land values, and it is necessary to have baseline information on the value of environmental attributes in order to identify potential policy and planning activities that can preserve these values. Current methods for assessing the value of non-market ecosystem services are mostly in development stages, with few widely-accepted approaches. Utilizing hedonic modeling and other revealed preference techniques may provide valuable insight into the contribution of nonmarket goods and services, in order to ensure they are adequately accounted for in planning and management decisions. 


\section{ACKNOWLEDGEMENTS}

I would like to thank my family and friends for their support throughout my time in graduate school, as well as my advisor Dr. David Ervin. Dr. Ervin provided invaluable encouragement and guidance during my master's program, and particularly during the production of this paper. I would also like to thank the PSU SESAME team: Dr. Heejun Chang, Terrance Anthony, Wes Hoyer, Mike Psaris, and Samantha Hamlin, and my MEM Community Partner, Dennis Yee of Metro. Additionally, I would like to thank Dan Bigelow, Ph.D. student at Oregon State University, for his patient responses to many questions over the past several months. 


\section{TABLE OF CONTENTS}

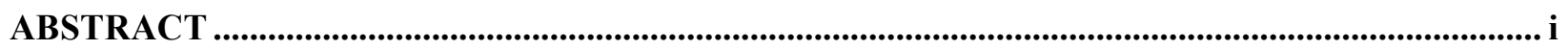

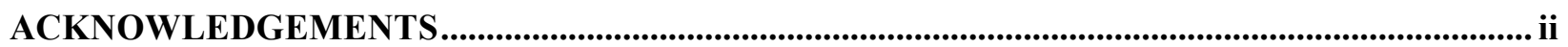

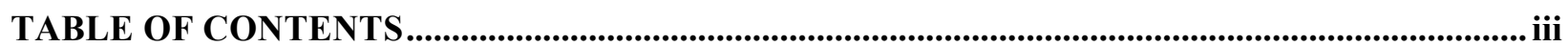

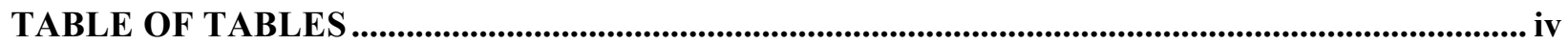

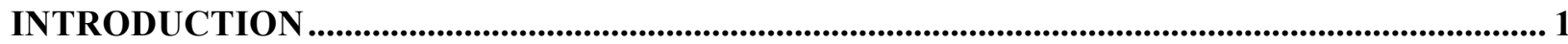

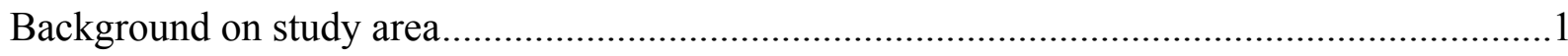

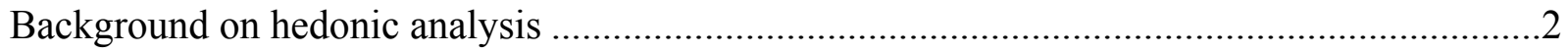

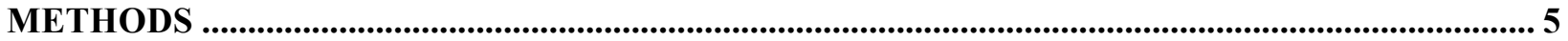

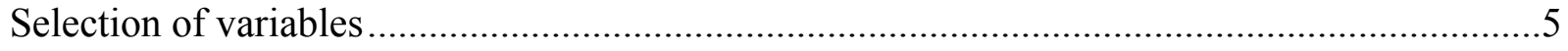

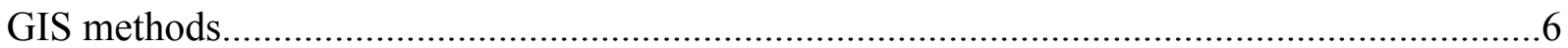

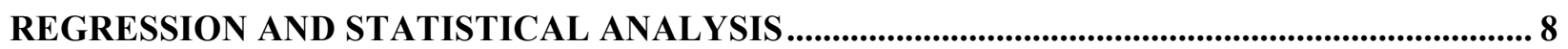

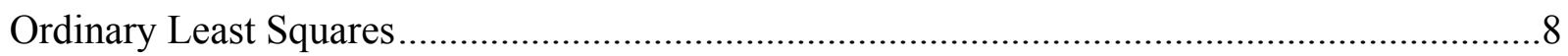

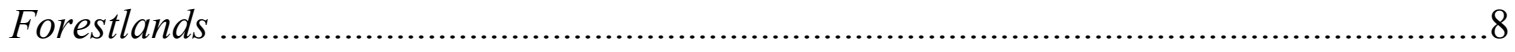

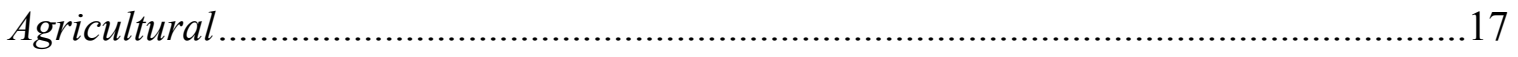

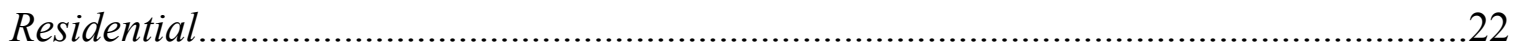

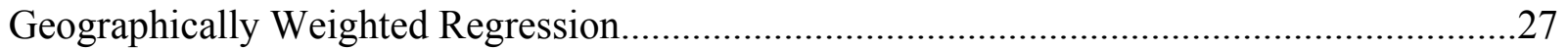

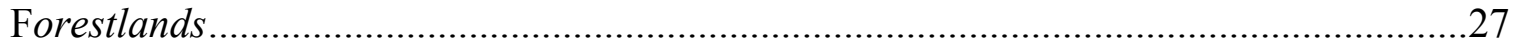

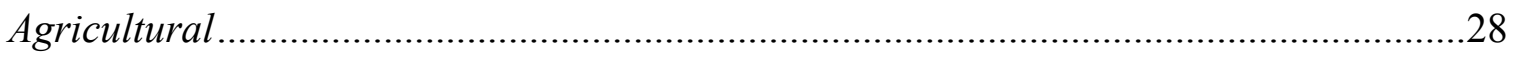

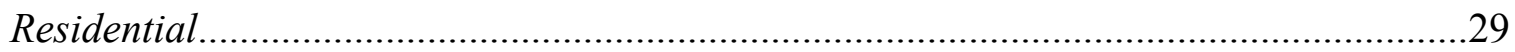

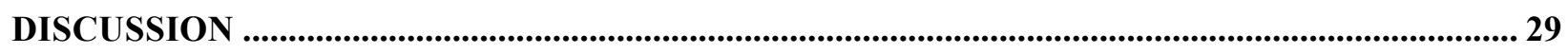

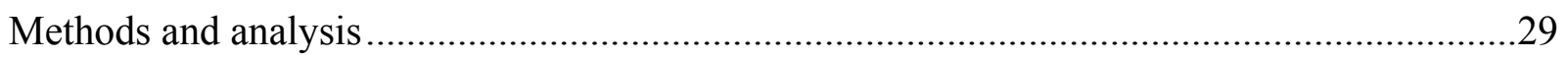

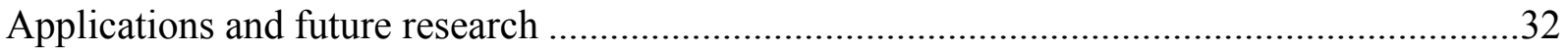

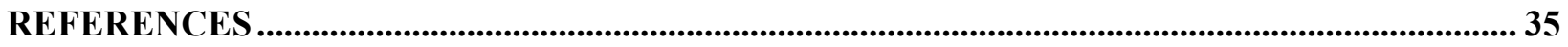




\section{TABLE OF TABLES}

Table 1 Explanatory variable datasets and sources ............................................................................7

Table 2 Variables considered for forest model ....................................................................99

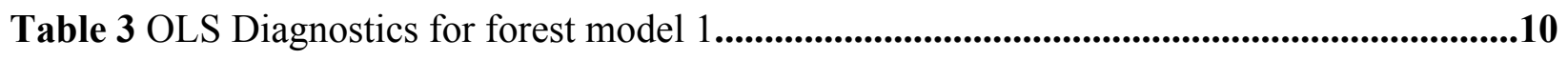

Table 4 Coefficients and significance of model 1 variables ........................................................12

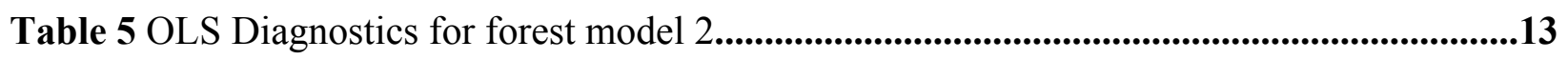

Table 6 Variables considered for agricultural model ............................................................17

Table 7 OLS Diagnostics for agricultural model 1 ............................................................18

Table 8 Coefficients and significance of model 1 variables ..........................................................20

Table 9 OLS Diagnostics for agricultural model 2 ........................................................................20

Table 10 Variables considered for residential model ..........................................................23

Table 11 OLS Diagnostics for residential model 1 ..............................................................24

Table 12 Coefficients and significance of model 1 variables ............................................................25

Table 13 OLS Diagnostics for residential model 2 ..................................................................26 


\section{INTRODUCTION}

\section{Background on study area}

Yamhill County is located in the Willamette Valley of Oregon and has a population of just over 100,000 (Oregon Blue Book 2013). An estimated one third of the County's 718 square miles is comprised of commercial timberland, representing a significant economic base for the area (Yamhill County Website 1996). Agricultural products including grains, nurseries, and orchards represent the other primary industry for the County. Wineries are also increasingly significant sources of agricultural production in Yamhill County; the County's 36 wineries represent the highest concentration of wineries in any Oregon county, and drive a valuable tourist industry as well (Oregon Blue Book 2013). Between 2000 and 2008, the population of Yamhill County grew $11 \%$, a trend that seems to be continuing, and there is a high commuting rate to the Portland area (Oregon Blue Book 2013). Because Yamhill County is located on the urban fringe, it has a high threat of development from city overflow and expansion from the Portland metropolitan area.

Oregon has a statewide land planning program that requires all cities and counties to produce plans and regulations that meet 19 statewide land use planning goals (Baker et al. 2004). One element of this is the implementation of urban growth boundaries (UGBs) that dictate the areas in which development can occur, in an attempt to reduce the effects of urban sprawl (Nelson and Moore 1993). Outside of the UGBs, land use is primarily restricted to resource uses including farming and forestry. While Oregon's development laws and urban growth boundaries will temper some of the sprawl, there are reserve areas that can be tapped for development, and there is the potential for amendments to the current policies. In 2004, Measure 37 was passed, allowing landowners whose property value is reduced by development restrictions to file claims 
for compensation (Oregon Department of Land Conservation and Development 2011). The ambiguities of this system made the measure somewhat controversial and difficult to implement, and the Measure was essentially replaced in 2007 by Measure 49. Measure 49 included significant amendments to Measure 37, attempting to clarify the options and processes for landowners to pursue compensation (ODLCD 2011). As of 2011, thousands of landowners had received compensation through Measure 49, primarily for rural farmlands. As population growth places more pressure on the Portland metropolitan area, the impacts of measures such as these will continue to be significant, and there will likely be attempts to expand the allowable development zones. This study is intended to provide insight into the effect that land conversion will have on market value of land in Yamhill County, in order to elucidate one component of the total land value in the area.

\section{Background on hedonic analysis}

There are a variety of environmental and socio-economic factors that affect land value. While characteristics such as improvements that exist on a given parcel may have a very clear linkage to the market value of the property, other elements such as proximity to a city or certain amenities as well as physical characteristics of the land itself may also play a significant role (Sander and Haight 2012). Hedonic models can be used to identify the characteristics that are most significantly driving the value of land (Bastian et al. 2002). This method is commonly used in land and property value estimations in an attempt to identify the impact that various attributes have on the market value of that property. While the most common application of hedonic modeling is examining the factors influencing housing prices (Snyder et al. 2007), this method has been extended to a variety of uses, particularly around the effects of environmental attributes. 
Recent studies have applied hedonic modeling to the impacts of rural amenities such as wildlife viewing, angling opportunities, and scenic views (Bastian et al. 2002), and have been expanded by inclusion of spatial elements. Sander and Haight (2012) also examined the impact of aesthetics (views) on property value, finding that this factor can significantly affect home sales prices. The hedonic model generated in this study showed that views of water and lawn, increased access to outdoor recreation areas, and increased levels of tree cover in a neighborhood all positively contributed to higher property prices. Incorporating the spatial component of property value is significant, and there has been notable growth in the field of spatial econometrics (Krause and Bitter 2012). These studies focus either on the effects of surrounding areas on a property's value (spatial dependence or neighborhood effect) (Geoghegan et al. 1997), or on modeling the spatial heterogeneity that can be observed across many landscapes wherein there are a variety of relationships occurring between property characteristics and property value (Krause and Bitter 2012). This study attempts to incorporate principles used in these types of studies in order to better understand the spatial context of land values in Yamhill County.

Ordinary Least Squares (OLS) regression is commonly used in developing hedonic models. This method assumes that a spatial stationary process is occurring between the dependent variable and the explanatory variables being examined, meaning that the way in which the variables interact is the same across space. However, in many cases the impact of features at one location in a study area may have a different effect on the dependent variable than in another location. An example of this is the variation that can be seen in housing market prices, wherein attributes that increase value significantly in one location may have a different impact elsewhere (Lochl and Axhausen 2010). Geographically Weighted Regression (GWR) is a regression technique that attempts to 
account for the spatial heterogeneity that may be present (Fotheringham et al. 2002). GWR can be useful because it allows for spatial variation in the relationships between the dependent and independent variables, providing a more accurate representation of the interactions occurring at a local scale. For this reason, GWR can enhance analysis of data that varies by spatial location and produce a more accurate predictive model by accounting for this variation. When GWR is run on a set of explanatory variables, a regression model is created for each of the data points, enabling a prediction of value for that specific location. This type of regression has many applications in the environmental field, allowing for spatially explicit analysis of patterns and processes.

The purpose of this study is to examine the factors contributing to land value of properties in Yamhill County, using Ordinary Least Squares regression as well as Geographically Weighted Regression. This analysis is being conducted as part of the Spatial Ecosystem Services Analysis, Modeling, and Evaluation (SESAME, http://www.pdx.edu/ecosystem-services/) project, a multiyear, interdisciplinary project that is exploring the effects of land use change and climate change on ecosystem services provision in the Willamette Valley. This paper discusses the process and preliminary results of the development of hedonic models that will be utilized for predicting land value changes under future land conversion scenarios. These scenarios are discussed further in the "Future Applications" section of this paper, and are being developed by other SESAME project members. Hedonic models based on current real market value of land in each of these use categories are being developed using a variety of physical and socio-economic variables. Once these models are finalized, they will be used in conjunction with the future land use scenarios to estimate the change in market value of land that can be expected with conversion of land from or to forest, agricultural, and residential lands. 


\section{Methods}

Because there are different real estate markets for each of the land use types that are being considered (agricultural, residential, and forestland), separate models need to be developed for each of the categories (Freeman 1979; Shonkwiler and Reynolds 1996). Following is a description of the processes used in model development.

\section{Selection of variables}

The selection of explanatory variables in hedonic models is not guided by a standard set of principles, and is often heavily influenced by data availability and judgment of the author (Freeman 1979; Bastian et al 2002; Snyder et al. 2007). Freeman (1979) goes so far as to assert that most studies in this sphere demonstrate some level of challengeable assumptions or variable selections. In light of this reality, selection of potential predictive variables for this study was based on examples of previous studies (Yoo et al. 2012; Sander and Haight 2012; Anderson and West 2006), as well as general understanding of the study area and the factors that may be influencing property value. Additionally, many iterations of model form were developed and tested using a combination of theoretical basis as well as trial and error (although only select versions were described in detail).

One important feature of this study was the use of Geographic Information Systems (GIS) to incorporate variables such as proximity to certain environmental and socio-economic amenities, soil type, slope and elevation, and other characteristics that can impact land values. Including spatially explicit attributes allows for assessment of value at a specific location and may produce more accurate estimations of the impacts of these explanatory variables (Bastian et al 2002). 
Therefore, the gathering, processing, and analysis of data were conducted primarily in ArcGIS 10.0 .

\section{GIS Methods}

The certified tax roll and associated shapefile for 2012 were obtained from the Yamhill County Tax Assessor's office. This data contains the assessed value of the land and improvements (as separate values) of each taxlot in the county, as well as attributes including acres and property class. The total number of parcels in this dataset was 42,641 , with 5,463 identified as agricultural, 21,375 as residential, and 3,388 as forestland. A random sample was drawn from these parcels using the Sampling Design Tool for ArcGIS (http://ccma.nos.noaa.gov/products/biogeography/sampling/) developed by NOAA. Using the option to draw a stratified sample, $2 \%$ of the parcels within each land use category (agriculture, residential, and forest) were selected as sample plots. After removing duplicated and/or erroneous parcel records, this resulted in 80 agricultural, 288 residential, and 51 forest land parcels. The study could potentially have benefitted from a larger sample, but the percentage of parcels used (2\%) was chosen when the intention was to conduct the same analysis on Washington County data, an area with significantly more taxlots and $2 \%$ of the parcels was selected to be a manageable amount of data to work with. Since the study ended up focusing on Yamhill County, which has a smaller tax roll, the percentage of parcels selected for the sample could have increased, but this change in research scope occurred after data processing was already underway and there was not time to redo that work. 
Once the sample parcels had been identified, datasets for all potential explanatory variables were gathered, processed, and assembled into a single database in ArcGIS.

Table 1. Datasets and sources.

\begin{tabular}{|c|c|c|c|}
\hline Variable & Source & Variable & Source \\
\hline Acres of taxlot & $\begin{array}{l}\text { Yamhill County tax } \\
\text { assessor's office } \\
(2012)\end{array}$ & $\begin{array}{l}\text { Designation as } \\
\text { Private Non- } \\
\text { industrial forest }\end{array}$ & $\begin{array}{l}\text { Oregon GEO Spatial } \\
\text { Data Library, } 1991\end{array}$ \\
\hline RMV of land & $\begin{array}{l}\text { Yamhill County tax } \\
\text { assessor's office } \\
(2012)\end{array}$ & $\begin{array}{l}\text { Forest Zone } \\
\text { Designation }\end{array}$ & $\begin{array}{l}\text { Oregon GEO Spatial } \\
\text { Data Library } \\
\text { (Department of Land } \\
\text { Conservation and } \\
\text { Development, 1986) }\end{array}$ \\
\hline $\begin{array}{l}\text { RMV of } \\
\text { improvements }\end{array}$ & $\begin{array}{l}\text { Yamhill County tax } \\
\text { assessor's office } \\
(2012)\end{array}$ & $\begin{array}{l}\text { Distance to Nearest } \\
\text { River }\end{array}$ & $\begin{array}{l}\text { Oregon GEO Spatial } \\
\text { Data Library (US } \\
\text { Geological Survey, } \\
\text { 1996) }\end{array}$ \\
\hline $\begin{array}{l}\text { Distance to nearest } \\
\text { city with population } \\
\text { greater than } 20 \mathrm{k}\end{array}$ & $\begin{array}{l}\text { US Census Bureau } \\
(2000)\end{array}$ & $\begin{array}{l}\text { Population of } \\
\text { nearest city }\end{array}$ & $\begin{array}{l}\text { US Census Bureau } \\
(2000)\end{array}$ \\
\hline $\begin{array}{l}\text { Per Capita Income } \\
\text { of Nearest City }\end{array}$ & $\begin{array}{l}\text { US Census Bureau } \\
(2000)\end{array}$ & $\begin{array}{l}\text { Land Capability } \\
\text { Classes (soil quality; } \\
\text { LCC1 is highest } \\
\text { quality, LCC } 8 \text { is } \\
\text { worst) }\end{array}$ & $\begin{array}{l}\text { USDA Natural } \\
\text { Resources } \\
\text { Conservation Service } \\
\text { Soil Data Mart } \\
\text { (2012) }\end{array}$ \\
\hline $\begin{array}{l}\text { Distance to nearest } \\
\text { highway }\end{array}$ & $\begin{array}{l}\text { Oregon GEO Spatial } \\
\text { Data Library (Oregon } \\
\text { Department of } \\
\text { Transportation, 2011) }\end{array}$ & $\begin{array}{l}\text { Urban Growth } \\
\text { Boundary }\end{array}$ & $\begin{array}{l}\text { Oregon GEO Spatial } \\
\text { Data Library (Dept. } \\
\text { of Land Conservation } \\
\text { and Development, } \\
2011 \text { ) }\end{array}$ \\
\hline $\begin{array}{l}\text { Irrigation Water } \\
\text { Rights (whether } \\
\text { there is an } \\
\text { irrigation right } \\
\text { present) }\end{array}$ & $\begin{array}{l}\text { Oregon Water } \\
\text { Resources } \\
\text { Department (2008) }\end{array}$ & $\begin{array}{l}\text { Average elevation } \\
\text { and average slope } \\
\text { (30 meter) }\end{array}$ & $\begin{array}{l}\text { USGS Digital } \\
\text { Elevation Models } \\
(2009)\end{array}$ \\
\hline
\end{tabular}


During model development in this study, several potential dependent variables were considered and tested: real market value (RMV) of the land, natural $\log$ of RMV of land, per-acre value of land, and natural log of per-acre value of land. For all three land use categories, the natural log of RMV of land produced a more normal distribution of values than the three other options that were considered, and this was selected as the dependent variable.

\section{RegResSion AND Statistical ANALysis}

\section{Ordinary Least Squares Regression}

Below is a description of the processes used to refine the models for each of the three land use categories, based on the variables discussed previously.

\section{Forestlands}

Below is a table (Table 2) consisting of the variables that were evaluated for inclusion in the model to describe forestland value. It should be noted that there are few examples in the literature that examine contributing factors to forestland values, a finding that is noted by Snyder et al. (2007). Therefore, hypotheses of the impact of explanatory variables were based on these few studies, as well as general patterns of land value variation and familiarity with the study area. 
Table 2. Variables considered for inclusion in the forestland model and expected impact.

\begin{tabular}{|c|c|c|c|c|c|}
\hline Variable & Units & Range & Mean & Effect & Rationale \\
\hline $\begin{array}{l}\text { Acres of } \\
\text { taxlot }\end{array}$ & Acres & $\begin{array}{l}6.6- \\
988.7 \\
\end{array}$ & 164.2 & + & $\begin{array}{l}\text { The value of a taxlot is expected to increase } \\
\text { with higher acreage. }\end{array}$ \\
\hline $\begin{array}{l}\text { Distance to } \\
\text { city w/ } \\
\text { population } \\
>20 k\end{array}$ & $\mathrm{Km}$ & $\begin{array}{l}15.6- \\
140.6\end{array}$ & 66.2 & - & $\begin{array}{l}\text { Proximity to a larger city is expected to } \\
\text { increase the value of a taxlot due to } \\
\text { increased access to amenities and markets, } \\
\text { as well as land development pressures } \\
\text { (Snyder et al. 2007). }\end{array}$ \\
\hline $\begin{array}{l}\text { Distance to } \\
\text { nearest } \\
\text { river }\end{array}$ & $\mathrm{Km}$ & $\begin{array}{l}0.008- \\
8.9\end{array}$ & 1.9 & - & $\begin{array}{l}\text { Proximity to a river is expected to increase } \\
\text { the value of the land due to the amenity } \\
\text { value of water sources. }\end{array}$ \\
\hline $\begin{array}{l}\text { Distance to } \\
\text { nearest } \\
\text { highway }\end{array}$ & $\mathrm{Km}$ & $\begin{array}{l}1.5- \\
33.4\end{array}$ & 13.9 & - & $\begin{array}{l}\text { Proximity to a highway is expected to } \\
\text { increase the value of a taxlot due to } \\
\text { increased transportation options, providing } \\
\text { access to amenities and markets. }\end{array}$ \\
\hline $\begin{array}{l}\text { Population } \\
\text { of nearest } \\
\text { city }\end{array}$ & $\begin{array}{l}\text { Thous- } \\
\text { ands } \\
\text { of } \\
\text { people }\end{array}$ & $\begin{array}{l}0.6- \\
26.5\end{array}$ & 9.0 & + & $\begin{array}{l}\text { Proximity to a larger city is expected to } \\
\text { increase land value because of the higher } \\
\text { demand for land nearer to urban areas and } \\
\text { access to markets. }\end{array}$ \\
\hline $\begin{array}{l}\text { Per capita } \\
\text { income of } \\
\text { nearest } \\
\text { city }\end{array}$ & $\begin{array}{l}\text { Thous- } \\
\text { ands } \\
\text { of } \$\end{array}$ & $\begin{array}{l}14.7- \\
31.2\end{array}$ & 19.6 & + & $\begin{array}{l}\text { Proximity to a city with higher per capita } \\
\text { income is expected to increase the value of } \\
\text { land because of the higher demand for } \\
\text { locations near economically healthy cities. }\end{array}$ \\
\hline $\begin{array}{l}\text { Mean } \\
\text { slope of } \\
\text { taxlot }\end{array}$ & $\begin{array}{l}\text { Degre } \\
\text { es }\end{array}$ & $\begin{array}{l}0- \\
25.6\end{array}$ & 8.3 & + & $\begin{array}{l}\text { This variable was not expected to have a } \\
\text { significant impact on land value. However, } \\
\text { the high prevalence of upland forests in the } \\
\text { area was expected to produce a positive } \\
\text { relationship between slope and forestland } \\
\text { value. }\end{array}$ \\
\hline $\begin{array}{l}\text { Mean } \\
\text { elevation } \\
\text { of taxlot }\end{array}$ & Meters & $\begin{array}{l}37- \\
255\end{array}$ & 143.6 & + & $\begin{array}{l}\text { Similarly to slope, this variable was not } \\
\text { expected to have a significant impact, } \\
\text { however, higher elevation was expected to } \\
\text { be associated with higher value due to } \\
\text { higher proportion of forestland in the } \\
\text { upland areas. }\end{array}$ \\
\hline $\begin{array}{l}\text { Forest } \\
\text { Zone }(=1 \text { if } \\
\text { yes })\end{array}$ & Binary & 0 or 1 & & - & $\begin{array}{l}\text { Designation as a forest zone is } \\
\text { hypothesized to result in a lower parcel } \\
\text { value because it removes the value that } \\
\text { would be associated with potential future } \\
\text { development. }\end{array}$ \\
\hline $\begin{array}{l}\text { Private } \\
\text { Non- } \\
\text { industrial } \\
(=1)\end{array}$ & Binary & 0 or 1 & & - & $\begin{array}{l}\text { It was expected that lands in industrial } \\
\text { forest uses would result in a higher land } \\
\text { value than those in non-industrial. }\end{array}$ \\
\hline
\end{tabular}




\begin{tabular}{|l|l|l|l|l|l|}
\hline $\begin{array}{l}\text { LCC 2 (=1 } \\
\text { if in this } \\
\text { LCC) }\end{array}$ & Binary & 0 or 1 & & + & $\begin{array}{l}\text { It was expected that higher quality soil } \\
\text { classes (LCC 1-4) would have a positive } \\
\text { relationship with land value. }\end{array}$ \\
\hline $\begin{array}{l}\text { LCC 3 (=1 } \\
\text { if in this } \\
\text { LCC) }\end{array}$ & Binary & 0 or 1 & & + & $\begin{array}{l}\text { It was expected that higher quality soil } \\
\text { classes (LCC 1-4) would have a positive } \\
\text { relationship with land value. }\end{array}$ \\
\hline $\begin{array}{l}\text { LCC 4 (=1 } \\
\text { if in this } \\
\text { LCC) }\end{array}$ & Binary & 0 or 1 & & + & $\begin{array}{l}\text { It was expected that higher quality soil } \\
\text { classes (LCC 1-4) would have a positive } \\
\text { relationship with land value. }\end{array}$ \\
\hline $\begin{array}{l}\text { RMV of } \\
\text { Improvem } \\
\text { ent }\end{array}$ & $\begin{array}{l}\text { Thous } \\
\text { ands } \\
\text { of } \$\end{array}$ & $0-4.6$ & 26.7 & + & $\begin{array}{l}\text { This variable was not expected to have } \\
\text { much impact on the land value because } \\
\text { there were few instances of improvements } \\
\text { on the forestlands. }\end{array}$ \\
\hline
\end{tabular}

R Studio (www.rstudio.com) was used to obtain Pearson correlation coefficients for the variables in this model, and Distance to City and Distance to Highway showed a very strong correlation (0.93), resulting in a decision to omit the Highway variable. The rest of the variables from Table 2 were included. This model was found to be statistically significant, based on the OLS Diagnostics values that were generated. The key statistics for this model's performance are included in Table 3.

Table 3. OLS Diagnostics for Model \#1

\begin{tabular}{|l|l|l|l|}
\hline Statistic & Value & Probability & Statistically significant? \\
\hline Adjusted R-squared & 0.68 & & \\
\hline AIC & 90.9 & & \\
\hline Joint F-statistic & 9.1 & 0.000000 & Yes \\
\hline Joint Wald Statistic & 468.9 & 0.000000 & Yes \\
\hline Koenker (BP) & 9.9 & 0.703632 & No \\
\hline Jarque-Bera Statistic & 0.75 & 0.687641 & No \\
\hline
\end{tabular}


The statistically significant Joint F-Statistic and Joint Wald Statistics indicate that the overall model is statistically significant. The adjusted R-squared value of 0.68 indicates that $68 \%$ of the variation in the land values is explained by the variables included in this model. (The Multiple Rsquared value is higher, 0.76 , but it is more accurate to use the Adjusted $\mathrm{R}$ value because it accounts for model complexity resulting from the inclusion of many variables (ArcGIS Help 1). The Akaike's Information Criterion (AIC) value is useful for comparing different models for goodness of fit, with a smaller value indicating better performance. The Koenker (BP) statistic is a measure of stationarity, assessing whether the relationship between the independent and dependent variables is consistent across the study area. For this model, the Koenker (BP) value is not statistically significant, which suggests that the relationship between the predictive variables and the dependent variable for this study is consistent across the study area. This is a logical result since separate models are being created for each of three land use types (agriculture, forest, residential) and it is expected that the interactions that contribute to land value are similar within each use category. In other words, this study is assuming that the explanatory variables that impact land value and their relative impact will be consistent amongst the parcels that belong to the same land use category.

The Jarque-Bera statistic is used to evaluate model bias and determine whether the regression residuals are normally distributed. When this value is statistically significant, it indicates misspecification in the model, likely due to a significant explanatory variable that has not been included. Fortunately, this model did not have a statistically significant Jarque-Bera value. Running the Spatial Autocorrelation (Moran's I) tool produced a z-score of 0.54 and a p-value of 0.59 , suggesting that the regression residuals do not demonstrate spatial autocorrelation, and are 
spatially random. None of the individual variables have VIF scores above 7.5 , the threshold above which data redundancy is implicated, suggesting that there are not significant multicollinearity issues.

Table 4. Coefficients and statistical significance (indicated by *).

\begin{tabular}{|l|l|l|l|}
\hline Variable & Coefficient & Variable & Coefficient \\
\hline Acres & $0.0041^{*}$ & Mean elevation & -0.00076 \\
\hline $\begin{array}{l}\text { Private Non- } \\
\text { industrial }\end{array}$ & $0.87^{*}$ & Mean slope & 0.0025 \\
\hline $\begin{array}{l}\text { Distance to } \\
\text { River }\end{array}$ & $0.16^{*}$ & $\begin{array}{l}\text { Per Capita } \\
\text { Income of } \\
\text { Nearest City }\end{array}$ & $-0.096^{*}$ \\
\hline $\begin{array}{l}\text { Distance to City } \\
>\text { 20k }\end{array}$ & -0.0052 & LCC 2 & -0.21 \\
\hline $\begin{array}{l}\text { RMV of } \\
\text { Improvements }\end{array}$ & -0.0000 & LCC 3 & -0.46 \\
\hline $\begin{array}{l}\text { Forest Zone } \\
\text { Designation }\end{array}$ & -0.31 & LCC 4 & -0.012 \\
\hline $\begin{array}{l}\text { Population of } \\
\text { Nearest City }\end{array}$ & $0.027^{*}$ & & \\
\hline
\end{tabular}

There were several variables that did not follow the expected results in regard to impact on the dependent variable. These were: Distance to River, Per Capita Income, Mean Elevation, LCC 2, and LCC 3. Of these, Designation as PNI, Distance to River, and Per Capita Income were indicated as statistically significant, so will be discussed in further detail below. Mean elevation did not demonstrate a large impact on land value (as predicted), but did have a slightly negative relationship, which was not predicted. Similarly, LCC 2 and LCC 3 were expected to have a positive relationship with land value, but demonstrated negative correlations. These variables 
were not indicated as statistically significant, however, so the relationship will not be examined as thoroughly as the ones that appear to be contributing significantly to the model.

Variables from this model that were indicated as statistically significant were Acres, PNI Designation, Distance to River, Population of Nearest City, and Income of Nearest City. The next model included these five variables. Results are included in Table 5.

Table 5. OLS Diagnostics for Model \#2.

\begin{tabular}{|l|l|l|l|}
\hline Statistic & Value & Probability & Statistically significant? \\
\hline Adjusted R-squared & 0.696 & & \\
\hline AIC & 82.1 & & \\
\hline Joint F-statistic & 23.9 & 0.000000 & Yes \\
\hline Joint Wald Statistic & 185.8 & 0.000000 & Yes \\
\hline Koenker (BP) & 4.997 & 0.416261 & No \\
\hline $\begin{array}{l}\text { Jarque-Bera } \\
\text { Statistic }\end{array}$ & 0.33 & 0.848096 & No \\
\hline
\end{tabular}

This model produced an Adjusted R-squared value of 0.696, and had a statistically significant value for the Joint Wald statistic, indicating that the model as a whole is significant. The AIC value was very similar to the more inclusive model (82.1), suggesting that this is a comparable model in terms of fit. The Koenker (BP) value was again not statistically significant, indicating stationarity in the model, and the Jarque-Bera statistic was also not statistically significant. None of the variables had high VIF values, so there did not appear to be issues with multicollinearity. All five of the variables were found to be statistically significant at the 0.05 level.

The specifications for the final model that was used for geographically weighted regression are: 
$\operatorname{Ln}(R M V$ of land $)=12.3+0.0039 *$ Acres $+1.018 * P N I+0.125 *$ Distance to River +

$0.029 *$ Population $-0.073 *$ Income

\section{Discussion of variables included in final model}

In the semi-log form of regression used here, the coefficients represent the percent change of the dependent variable with one unit of change in the independent variable (Hayashi 2000).

Therefore, the coefficients in this model indicate that:

- An increase of one acre in parcel size is expected to increase the value of the property by $0.39 \%$

- An increase in proximity to a river of one kilometer is expected to increase price by $12.5 \%$

- An increase of one thousand people in the nearest city is expected to increase value by $2.9 \%$

- An increase of one thousand dollars in per capita income of the nearest city is expected to decrease value by $7.3 \%$.

- Properties designated as PNI are expected to have values that are $100 \%$ greater than those that are not PNI

Acres- The positive relationship between acres and the dependent variable indicates that an increase in acres results in an increase in price of the parcel. This was the expected result for this variable, given that a larger parcel of land would be assumed to have a higher value. 
PNI- There was a positive relationship between designation as PNI and land value, which was not the expected result. There are a wide variety of circumstances surrounding non-industrial private forests, so it is hard to pinpoint the reasons for this result, but one factor that may be important is simply that the large majority of parcels in the sample were designated as private non-industrial forestland. Additionally, Snyder et al. (2007) found that non-industrial private forestland ownership is often pursued for reasons other than timber production, so the land value of these areas is influenced by a variety of factors outside of harvest potential or value of timber stands. Therefore, this variable may be capturing other values in the land price, including recreation and/or aesthetic values. Another possibility is that the non-industrial private forestlands may be more likely to be developed than the industrial forestlands, suggesting a higher potential development value. In this case, the higher value for non-industrial lands may be reflective of speculative future value.

Distance to River-The positive relationship suggests that greater distance from a river increases the price of a given parcel. This result is counterintuitive, because in most cases land values increase with proximity to water resources (Snyder et al. 2007; Anderson and West 2006). However, as previously noted, there are few studies specifically evaluating these impacts on forest land value, so this could be a relationship that is unique to this land use type. Snyder et al. (2007) did specifically look at effects on forestland value, but they only assessed riverfront or lakefront access and did not address the impacts of proximity to water sources that were further away. This result may also be due to the topography and land use distribution of Yamhill County, where most of the forested areas are located further from rivers (or at least are less clustered around rivers) than the agricultural and residential parcels are. 
Population—As predicted, population of nearest city and parcel value were positively related, meaning that being near a larger city increases the parcel value. Urban rent theory suggests that the value of land is primarily determined by combination of transport costs and accessibility (Cheshire and Sheppard 1995). The relationship found here, then, indicates that increased land value is a factor of having access to jobs, shopping, services, and other amenities that urban centers provide. A similar trend was seen with distance to nearest highway, as that variable seems to capture access to urban centers and other amenities (it was removed for most versions of the models due to a high correlation with distance to city).

Income - Contrary to expectations, the model indicated a negative relationship between per capita income and taxlot value. This suggests that taxlots that are near cities with higher per capita income will have a lower value, which is counterintuitive. It is hard to explain this anomaly, and it may be indicative of a sampling issue. Closer examination of the forestland parcels shows that there are only three parcels that are closest to the city with the highest per capita income (Gaston), and all three of these are relatively low-value properties (the highest value is $\$ 140,500)$. Conversely, there are five parcels that are nearest to the city with the lowest income (Sheridan) and all of these parcels have higher values than the most valuable property near Gaston. Additionally, there are two parcels in this area that are among the highest parcel values in the sample ( $\$ 1.2$ million and $\$ 635,000)$. Perhaps with a larger sample this variable would act as expected and proximity to a higher-income city would increase parcel value. 


\section{Agricultural Lands}

Table 6 contains variables that were expected to contribute to the value of the dependent variable (natural log of real market value of the land), as well as an explanation of the expected impact of each variable.

Table 6. Variables considered for inclusion in the agricultural model and expected impact.

\begin{tabular}{|c|c|c|c|c|c|}
\hline Variable & Units & Range & Mean & Effect & Rationale \\
\hline Acres of taxlot & Acres & $\begin{array}{l}4.9- \\
1277 \\
\end{array}$ & 121.2 & + & $\begin{array}{l}\text { The value of a taxlot is expected to } \\
\text { increase with higher acreage. }\end{array}$ \\
\hline $\begin{array}{l}\text { RMV of } \\
\text { Improvements }\end{array}$ & $\begin{array}{l}\text { Thous- } \\
\text { ands of } \\
\$\end{array}$ & $\begin{array}{l}0- \\
857.4\end{array}$ & 120.9 & + & $\begin{array}{l}\text { More valuable improvements on the } \\
\text { property are expected to increase the value } \\
\text { of the land. }\end{array}$ \\
\hline $\begin{array}{l}\text { Distance to } \\
\text { city w/ } \\
\text { population > } \\
\text { 20k }\end{array}$ & $\mathrm{Km}$ & $\begin{array}{l}9.4- \\
88.6\end{array}$ & 36.8 & - & $\begin{array}{l}\text { Proximity to a larger city is expected to } \\
\text { increase the value of a taxlot due to } \\
\text { increased access to amenities. }\end{array}$ \\
\hline $\begin{array}{l}\text { Distance to } \\
\text { nearest river }\end{array}$ & $\mathrm{Km}$ & $\begin{array}{l}0.016- \\
6.8\end{array}$ & 1.6 & - & $\begin{array}{l}\text { Proximity to a river is expected to increase } \\
\text { the value of the land. }\end{array}$ \\
\hline $\begin{array}{l}\text { Distance to } \\
\text { nearest } \\
\text { highway }\end{array}$ & $\mathrm{Km}$ & $\begin{array}{l}0.29- \\
14.9\end{array}$ & 3.8 & - & $\begin{array}{l}\text { Proximity to a highway is expected to } \\
\text { increase the value of a taxlot due to } \\
\text { increased transportation options, providing } \\
\text { access to amenities and markets. }\end{array}$ \\
\hline $\begin{array}{l}\text { Population of } \\
\text { nearest city }\end{array}$ & $\begin{array}{l}\text { Thous- } \\
\text { ands of } \\
\text { people }\end{array}$ & $\begin{array}{l}0.354- \\
32.2\end{array}$ & 8.5 & + & $\begin{array}{l}\text { Proximity to a larger city is expected to } \\
\text { increase taxlot value because of the higher } \\
\text { demand for land nearer to urban areas. }\end{array}$ \\
\hline $\begin{array}{l}\text { Per capita } \\
\text { income of } \\
\text { nearest city }\end{array}$ & $\begin{array}{l}\text { Thous- } \\
\text { ands of } \\
\$\end{array}$ & $\begin{array}{l}14.7- \\
31.2\end{array}$ & 20.5 & + & $\begin{array}{l}\text { Proximity to a city with higher per capita } \\
\text { income is expected to increase the value of } \\
\text { land because of the higher demand for } \\
\text { locations near economically healthy cities. }\end{array}$ \\
\hline $\begin{array}{l}\text { Mean slope of } \\
\text { taxlot }\end{array}$ & Degree & $\begin{array}{l}0- \\
18.7\end{array}$ & 4.3 & - & $\begin{array}{l}\text { Increased slope is expected to decrease the } \\
\text { value of the land due to conditions that are } \\
\text { more challenging for agricultural activities } \\
\text { Steeper slopes also cause higher erosion } \\
\text { rates which can impact soil quality. }\end{array}$ \\
\hline $\begin{array}{l}\text { Mean } \\
\text { elevation of } \\
\text { taxlot }\end{array}$ & Meters & $\begin{array}{l}24.5- \\
255\end{array}$ & 97.3 & - & $\begin{array}{l}\text { The value of land is expected to decrease } \\
\text { with increased elevation, due to more } \\
\text { variability in temperature (more freezing } \\
\text { events, hotter conditions in summer } \\
\text { months). }\end{array}$ \\
\hline
\end{tabular}




\begin{tabular}{|l|l|l|l|l|l|}
\hline $\begin{array}{l}\text { EFU } \\
\text { designation } \\
\text { (=1 if yes) }\end{array}$ & Binary & 0 or 1 & & + & $\begin{array}{l}\text { The value of land is expected to be higher } \\
\text { for lands that are zoned for exclusive farm } \\
\text { use since these are areas that are well } \\
\text { suited for agricultural purposes. }\end{array}$ \\
\hline $\begin{array}{l}\text { LCC 1 (=1 if } \\
\text { in this LCC) }\end{array}$ & Binary & 0 or 1 & & + & $\begin{array}{l}\text { It was expected that higher quality soil } \\
\text { classes (LCC 1-4) would have a positive } \\
\text { relationship with land value. }\end{array}$ \\
\hline $\begin{array}{l}\text { LCC 2 (=1 if } \\
\text { in this LCC) }\end{array}$ & Binary & 0 or 1 & & + & $\begin{array}{l}\text { It was expected that higher quality soil } \\
\text { classes (LCC 1-4) would have a positive } \\
\text { relationship with land value. }\end{array}$ \\
\hline $\begin{array}{l}\text { LCC 3 (=1 if } \\
\text { in this LCC) }\end{array}$ & Binary & 0 or 1 & & + & $\begin{array}{l}\text { It was expected that higher quality soil } \\
\text { classes (LCC 1-4) would have a positive } \\
\text { relationship with land value. }\end{array}$ \\
\hline $\begin{array}{l}\text { LCC 4 (=1 if } \\
\text { in this LCC) }\end{array}$ & Binary & 0 or 1 & & + & $\begin{array}{l}\text { It was expected that higher quality soil } \\
\text { classes (LCC 1-4) would have a positive } \\
\text { relationship with land value. }\end{array}$ \\
\hline $\begin{array}{l}\text { Irrigation } \\
\text { water right } \\
\text { (=1 if present) }\end{array}$ & Binary & 0 or 1 & & + & $\begin{array}{l}\text { The value of land is expected to be higher } \\
\text { for lands that have a water right for } \\
\text { irrigation purposes. }\end{array}$ \\
\hline
\end{tabular}

The results for the model based on these variables are included in Table 7 .

Table 7. OLS Diagnostics for Model \#1.

\begin{tabular}{|l|l|l|l|}
\hline Statistic & Value & Probability & Statistically significant? \\
\hline Adjusted R-squared & 0.55 & & \\
\hline AIC & 159.2 & & \\
\hline Joint F-statistic & 7.4 & 0.000000 & Yes \\
\hline Joint Wald Statistic & 140.6 & 0.000000 & Yes \\
\hline Koenker (BP) & 13.5 & 0.565122 & No \\
\hline Jarque-Bera Statistic & 46.5 & 0.000000 & Yes \\
\hline
\end{tabular}

The Joint F-Statistic and Joint Wald Statistics were both statistically significant, indicating that the overall model is statistically significant. The adjusted R-squared value of 0.55 indicates that $55 \%$ of the variation in the land values is explained by the variables included in this model. This value is lower than the R-squared value that was produced by the forestlands model, and the AIC 
value also indicates lower performance by this model. The AIC value for the forest model was 82, which is much smaller than the value of 159 found for this model (for AIC, smaller values indicate better fit of the model).

The Koenker (BP) value is not statistically significant for this model, suggesting that there are not issues with non-stationarity. Running the Spatial Autocorrelation (Moran's I) tool produced a z-score of 0.299 and a p-value of 0.76 , which are within the acceptable range for normal distribution. However, the Jarque-Bera statistic is statistically significant for this model, indicating possible misspecification in the model due to a missing explanatory variable, or outliers that are influencing the model (ArcGIS help 2). It is unclear, or at least debated, in the literature as to how meaningful this result is in indicating model validity, and further discussion of the considerations around this indication of model bias is included later in this paper. All of the variables available for use in this study have been tested for model suitability, so if there is a key predictor missing, it is because that data has not been collected for this study and will have to be addressed in future analysis. Therefore, model development continued according to the same process that was used for the forest data, but was conducted with the understanding that there may be a misspecification in the model. 
Table 8. Coefficients and statistical significance (indicated by *).

\begin{tabular}{|l|l|l|l|}
\hline Variable & Coefficient & Variable & Coefficient \\
\hline Acres & $0.0037^{*}$ & Distance to Highway & -0.0096 \\
\hline Distance to City & $-0.015^{*}$ & Distance to River & -0.027 \\
\hline Irrigation & 0.0076 & Mean Elevation & -0.00037 \\
\hline EFU & -0.35 & Mean Slope & -0.0058 \\
\hline LCC 1 & -0.013 & Population & $0.018^{*}$ \\
\hline LCC 2 & -0.068 & Income & -0.012 \\
\hline LCC 3 & 0.013 & $\begin{array}{l}\text { RMV of } \\
\text { Improvements }\end{array}$ & 0.00059 \\
\hline LCC 4 & 0.41 & & \\
\hline
\end{tabular}

There were several variables that did not follow the expected results in regard to impact on the dependent variable. These were: Per Capita Income, EFU designation, LCC 1, and LCC 2. However, none of these were indicated as statistically significant, so these relationships were not investigated further. Variables from this model that were indicated as statistically significant were Acres, Distance to City, and Population of Nearest City. The next model included these three variables. Results are included in Table 9.

Table 9. OLS Diagnostics for Model \#2.

\begin{tabular}{|l|l|l|l|}
\hline Statistic & Value & Probability & Statistically significant? \\
\hline Adjusted R-squared & 0.58 & & \\
\hline AIC & 143.1 & & \\
\hline Joint F-statistic & 37.3 & 0.000000 & Yes \\
\hline Joint Wald Statistic & 52.9 & 0.000000 & Yes \\
\hline Koenker (BP) & 2.6 & 0.454151 & No \\
\hline Jarque-Bera Statistic & 56.1 & 0.000000 & Yes \\
\hline
\end{tabular}


The R-squared and AIC values improved slightly with this model, and the diagnostics indicated that it is a statistically significant model. The Koenker (BP) statistic still did not indicate nonstationarity issues. As in the previous models for this data, however, the Jarque-Bera statistic suggests a potential flaw in the model specifications. It may be useful to run Hot Spot analysis on the OLS model to identify patterns of features that are over or under predicting. This analysis could provide insight into the spatial factors that could be influencing certain data points and/or suggest potential attributes that could contribute to the explanatory value of the model. See the discussion section for more details on the possible causes and implications of this statistical result.

All three of the variables in the final model were statistically significant, and specifications are: $\operatorname{Ln}(R M V$ of Land $)=12.6+0.0037 *$ Acres $-0.011 *$ Distance to City $+0.018 *$ Population

Discussion of variables included in final model:

Acres-The positive relationship between acres and value of land is expected, as a larger property would intuitively increase the value of the property.

Distance to City - The negative relationship between Distance to City and parcel value indicates that properties that are further from a city with a population of at least 20,000 have lower values. This is an intuitive finding, since higher property values tend to be found closer to city areas. This is likely a reflection of proximity to jobs, goods and services, and other amenities associated with urban centers. 
Population-The positive relationship between Population of Nearest City and parcel value is expected. Similar to the relationship between Distance to City and land value, it is expected that the parcel value will increase for properties that are nearer to larger cities.

Note: It was surprising that the LCC variables were not found to be statistically significant, as it would seem as though soil quality would be an important factor in the value of agricultural lands. However, it is possible that the format of these variables - dummy variables with a one assigned to parcels that are primarily $\mathrm{LCC} 1, \mathrm{LCC} 2, \mathrm{LCC} 3$, or $\mathrm{LCC} 4$ - did not adequately capture the effect of this attribute. There is further discussion of this possibility as well as other options presented in the methods discussion section of this paper.

\section{$\underline{\text { Residential Lands }}$}

Table 10 contains variables that were expected to contribute to the value of the dependent variable (natural $\log$ of real market value of the land), as well as an explanation of the expected impact of each variable. Table 11 contains the results for this model. 
Table 10. Variables considered for inclusion in the residential model and expected impact.

\begin{tabular}{|c|c|c|c|c|c|}
\hline Variable & Units & Range & Mean & Effect & Rationale \\
\hline Acres of taxlot & Acres & $\begin{array}{l}0- \\
50.6\end{array}$ & 0.91 & + & $\begin{array}{l}\text { The value of a taxlot is expected to increase } \\
\text { with higher acreage. }\end{array}$ \\
\hline $\begin{array}{l}\text { RMV of } \\
\text { Improvements }\end{array}$ & $\begin{array}{l}\text { Thous- } \\
\text { ands } \\
\text { of } \$\end{array}$ & $\begin{array}{l}0- \\
13,551\end{array}$ & 201.4 & + & $\begin{array}{l}\text { More valuable improvements on the } \\
\text { property is expected to increase the value of } \\
\text { the land. }\end{array}$ \\
\hline $\begin{array}{l}\text { Distance to } \\
\text { city w/ } \\
\text { population }> \\
20 \mathrm{k}\end{array}$ & $\mathrm{Km}$ & $\begin{array}{l}0- \\
91.9\end{array}$ & 19.3 & - & $\begin{array}{l}\text { Proximity to a larger city is expected to } \\
\text { increase the value of a taxlot due to } \\
\text { increased access to jobs, goods and services, } \\
\text { and other amenities that an urban center } \\
\text { provides. }\end{array}$ \\
\hline $\begin{array}{l}\text { Distance to } \\
\text { nearest river }\end{array}$ & $\mathrm{Km}$ & $\begin{array}{l}0.003- \\
4.7\end{array}$ & 1.4 & - & $\begin{array}{l}\text { Proximity to a river is expected to increase } \\
\text { the value of the land due to recreational and } \\
\text { aesthetic benefits. }\end{array}$ \\
\hline $\begin{array}{l}\text { Distance to } \\
\text { nearest } \\
\text { highway }\end{array}$ & $\mathrm{Km}$ & $\begin{array}{l}0.10- \\
14.9\end{array}$ & 3.4 & - & $\begin{array}{l}\text { Proximity to a highway is expected to } \\
\text { increase the value of a taxlot due to } \\
\text { increased transportation options, providing } \\
\text { access to amenities and markets. }\end{array}$ \\
\hline $\begin{array}{l}\text { Population of } \\
\text { nearest city }\end{array}$ & $\begin{array}{l}\text { Thous- } \\
\text { ands } \\
\text { of } \\
\text { people }\end{array}$ & $\begin{array}{l}0.794- \\
26.5\end{array}$ & 15.2 & + & $\begin{array}{l}\text { Proximity to a larger city is expected to } \\
\text { increase taxlot value because of the higher } \\
\text { demand for land nearer to urban areas. }\end{array}$ \\
\hline $\begin{array}{l}\text { Per capita } \\
\text { income }\end{array}$ & $\begin{array}{l}\text { Thous- } \\
\text { ands } \\
\text { of } \$\end{array}$ & $\begin{array}{l}14.7- \\
30.0\end{array}$ & 21.0 & + & $\begin{array}{l}\text { Proximity to a city with higher per capita } \\
\text { income is expected to increase the value of } \\
\text { land because of the higher demand for } \\
\text { locations near economically healthy cities. }\end{array}$ \\
\hline $\begin{array}{l}\text { Mean slope of } \\
\text { taxlot }\end{array}$ & Degrees & $0-24.2$ & 2.6 & - & $\begin{array}{l}\text { Increased slope is expected to decrease the } \\
\text { value of the land due to conditions that are } \\
\text { more challenging for development activities. }\end{array}$ \\
\hline $\begin{array}{l}\text { LCC } 1(=1 \text { if in } \\
\text { this LCC) }\end{array}$ & Binary & 0 or 1 & & + & $\begin{array}{l}\text { It was expected that higher quality soil } \\
\text { classes (LCC 1-4) would have a positive } \\
\text { relationship with land value. }\end{array}$ \\
\hline $\begin{array}{l}\text { LCC } 2(=1 \text { if in } \\
\text { this LCC) }\end{array}$ & Binary & 0 or 1 & & + & $\begin{array}{l}\text { It was expected that higher quality soil } \\
\text { classes (LCC 1-4) would have a positive } \\
\text { relationship with land value. }\end{array}$ \\
\hline $\begin{array}{l}\text { LCC } 3(=1 \text { if in } \\
\text { this LCC) }\end{array}$ & Binary & 0 or 1 & & + & $\begin{array}{l}\text { It was expected that higher quality soil } \\
\text { classes (LCC 1-4) would have a positive } \\
\text { relationship with land value. }\end{array}$ \\
\hline $\begin{array}{l}\text { LCC } 4(=1 \text { if in } \\
\text { this LCC })\end{array}$ & Binary & 0 or 1 & & + & $\begin{array}{l}\text { It was expected that higher quality soil } \\
\text { classes (LCC 1-4) would have a positive } \\
\text { relationship with land value. }\end{array}$ \\
\hline
\end{tabular}


Table 11. OLS Diagnostics for Model \#1.

\begin{tabular}{|l|l|l|l|}
\hline Statistic & Value & Probability & Statistically significant? \\
\hline Adjusted R-squared & 0.48 & & \\
\hline AIC & 510.6 & & \\
\hline Joint F-statistic & 22.3 & 0.000000 & Yes \\
\hline Joint Wald Statistic & 184.7 & 0.000000 & Yes \\
\hline Koenker (BP) & 38.4 & 0.000134 & Yes \\
\hline Jarque-Bera Statistic & 5296.0 & 0.000000 & Yes \\
\hline
\end{tabular}

The Joint F-Statistic and Joint Wald Statistics were both statistically significant, indicating that the overall model is statistically significant. The adjusted R-squared value of 0.48 indicates that $48 \%$ of the variation in the land values is explained by the variables included in this model.

The Koenker (BP) value for this model is statistically significant, suggesting that there are issues with non-stationarity. This is not a surprising outcome, as residential properties would logically be the most difficult to model. There is a lot of variation in the structure and layout of taxlots that fall under the category of residential, which could result in a broad range of data values appearing in this category. Like with the agriculture model, the Jarque-Bera statistic is statistically significant, indicating possible misspecification in the model due to a missing explanatory variable. Running the Spatial Autocorrelation (Moran's I) tool produced a z-score of 1.3 and a p-value of 0.21 , which is within the range suggesting a normal distribution of residuals. As with the agricultural model, it is unclear whether there is a real issue with the model specifications, or if the Jarque-Bera result is being thrown off due to outliers or some other cause. This result is particularly unclear due to the acceptable result for the Spatial 
Autocorrelation test. Again, model development continued but was conducted with the understanding that there may be a misspecification in the model.

Table 12: Coefficients and statistical significance (indicated by *).

\begin{tabular}{|l|l|l|l|}
\hline Variable & Coefficient & Variable & Coefficient \\
\hline Acres & $0.16^{*}$ & LCC 1 & -0.53 \\
\hline Distance to city & 0.0023 & LCC 2 & -0.23 \\
\hline Distance to highway & -0.0036 & LCC 3 & -0.31 \\
\hline Distance to river & 0.037 & LCC 4 & 0.044 \\
\hline Mean slope & 0.0022 & Income & $0.044^{*}$ \\
\hline Population & $0.016^{*}$ & $\begin{array}{l}\text { RMV of } \\
\text { improvements }\end{array}$ & -0.00014 \\
\hline
\end{tabular}

There were several variables that did not follow the expected results in regard to impact on the dependent variable. These were: Distance to City, Distance to River, Slope, LCC 1, LCC 2, and LCC 3. However, none of these were indicated as statistically significant, so these relationships were not investigated further. The statistically significant variables from this model were used to run the next iteration. These were Acres, Population of Nearest City, and Income of Nearest City. Results of this model are included in Table 13. 
Table 13: OLS Diagnostics for Model \#2.

\begin{tabular}{|l|l|l|l|}
\hline Statistic & Value & Probability & Statistically significant? \\
\hline Adjusted R-squared & 0.46 & & \\
\hline AIC & 511.2 & & \\
\hline Joint F-statistic & 83.1 & 0.000000 & Yes \\
\hline Joint Wald Statistic & 34.1 & 0.000000 & Yes \\
\hline Koenker (BP) & 35.4 & 0.000000 & Yes \\
\hline Jarque-Bera Statistic & 4504.5 & 0.000000 & Yes \\
\hline
\end{tabular}

The model is statistically significant according to the OLS diagnostics, and the adjusted Rsquared value was virtually the same as in the previous model. The AIC value went down slightly, indicating a slightly better fit with this model (this was a very small change however). The Koenker (BP) value is statistically significant for this model, suggesting that this model does have issues with non-stationarity, as the prior one did. The Spatial Autocorrelation (Moran's I) tool gives a z-score of 1.36 and a p-value of 0.17 , which indicates a normal distribution, but the Jarque-Bera statistic still indicates a possible misspecification in the model due to a missing explanatory variable. As discussed previously, this indicates a potential flaw in the model, but not one that can be addressed at this point, as it may require the inclusion of additional variables that are not available for this process.

All three of the variables were statistically significant and the specifications for the final model are:

$\operatorname{Ln}(R M V$ of land $)=10.4+0.131 *$ Acres $+0.013 *$ Population $+0.038 *$ Income 
Acres-The positive relationship between acres and value of land is expected, as a larger property would intuitively increase the value of the property.

Population - The positive relationship between Population of Nearest City and parcel value is expected, as properties that are nearer to larger cities tend to command higher prices.

Income-The positive relationship between taxlot value and Per Capita Income of the nearest city is intuitive because larger cities will tend to have a higher per capita income, and will also influence the demand for and value of the land in the surrounding area.

\section{GEOGRAPHICALLY Weighted REGRESSION}

\section{Forestlands}

The final OLS model was then evaluated using geographically weighted regression (GWR).

GWR can be particularly useful for addressing issues of non-stationarity, but the final model produced through OLS did not have diagnostic values indicating that this was a problem. Therefore, using GWR would demonstrate what contribution spatial regression could make to a stationary model.

The results for GWR using the specifications of the OLS model were:

\begin{tabular}{|l|l|l|}
\hline Statistic & GWR Value & OLS Value \\
\hline R-squared & 0.696 & 0.696 \\
\hline AIC & 86.7 & 82.1 \\
\hline
\end{tabular}


There was minimal improvement using GWR with the specifications from the OLS model. This is not surprising given that the model did not demonstrate non-stationarity, and seems to be exhibiting consistent relationships among the independent and dependent variables across the landscape.

\section{Agriculture Lands}

The final OLS model was then evaluated using geographically weighted regression (GWR).

GWR can be particularly useful for addressing issues of non-stationarity, but the final model produced through OLS did not have diagnostic values indicating that this was a problem. Therefore, using GWR would demonstrate what contribution spatial regression could make to a stationary model.

The results for GWR using the specifications of the OLS model were:

\begin{tabular}{|l|l|l|}
\hline Statistic & GWR Value & OLS Value \\
\hline R-squared & 0.61 & 0.58 \\
\hline AIC & 140.9 & 143.1 \\
\hline
\end{tabular}

There was some improvement using GWR with the specifications from the OLS model. The Rsquared value increased from 0.58 to 0.61 , and the AIC went down very slightly. However, these were very small changes, and more exploration of the potential issues with the diagnostic results from the OLS model is necessary to determine whether the model specifications are useful. 


\section{Residential Lands}

\begin{tabular}{|l|l|l|}
\hline Statistic & GWR Value & OLS Value \\
\hline R-squared & 0.48 & 0.46 \\
\hline AIC & 503.1 & 511.2 \\
\hline
\end{tabular}

There was little improvement using GWR with the specifications from the OLS model. The Rsquared value increased from 0.46 to 0.48 , and the AIC went down from 511 to 503 . As with the other models, these were very small changes, and more exploration of the potential issues with the diagnostic results from the OLS model is necessary to determine whether the model specifications are useful. It was expected that the residential model would benefit more from GWR than the other two, given that it did indicate non-stationarity issues. It is hard to determine why this wasn't the case; perhaps it is a reflection of a misspecification in the model that will require the inclusion of additional variables to provide a better explanatory model.

\section{DISCUSSION}

\section{Methods and analysis}

The R-squared and AIC values for the models produced here were fairly strong and similar to those found in other studies (Bastian et al. 2002, Geoghegan et al. 1997). However, some of the results were contrary to what would be expected, and the residential and agricultural models both reflected potential bias in their specifications. The residential model was re-run using the natural log of key independent variables, and saw improvement in R-squared value and AIC value, but still indicated the issues with model bias and non-stationarity, and had worse scores for those statistics. This version also had a very high z-score (4.3) and low p-value (0.000014) for the 
Spatial Autocorrelation test, indicating that the residuals were not randomly distributed over space. As noted in the ArcGIS help resources (ArcGIS help 2), a model can have a high Rsquared value but still not be performing well. Particularly if a model fails the tests that indicate bias, it might be representing the interactions between variables well in some areas but not in others, or only under certain conditions, which makes it an unreliable model. Therefore, the original model was kept and transformed independent variables were not used for any of the models.

The indication of bias or model misspecification in the residential and agricultural models is concerning. As mentioned previously, this could mean that one or more key variables are missing from the models. Particularly for the residential model, it seems likely that there is one (or more) variable missing from the model specifications. The variables that were used in developing these models are most applicable to agricultural or forested taxlots, and less encompassing of factors that would affect more developed areas. Therefore, identifying and including attributes that would likely contribute to land value in a more urban setting could greatly improve this model. Using Hot Spot analysis in ArcGIS could be useful in identifying areas where there are multiple over- or under-predictions and looking at the geographic features in that area to try to infer a pattern or particular attribute that may help explain the deviation. It could be that there is something unique about certain locations in the study area that requires additional explanatory variables (e.g. a physical feature of the landscape, unique zoning or other development-related restriction, etc.). Another possibility is that variables that were included in this study were not capturing their intended value. In the agricultural model, it seems possible that the LCC (soil quality) variables did not appropriately reflect the impact that this attribute 
would have on the value of agricultural land. This may be because a dummy variable method was used in this analysis, and this may not have been an adequate approach for capturing the full effect of soil quality on agricultural production and land value. A more robust approach may be to calculate the proportion of each taxlot that is covered by each LCC and use that value as an explanatory variable. This method will be considered for inclusion in the next steps of this study.

Another consideration is that the Jarque-Bera statistic has received some criticism regarding its usefulness in assessing normal distribution. Brys et al. (2004) have proposed that other measures of normality may be more effective than Jarque-Bera which can be overly sensitive to outliers. Given the potential for high variation among land parcels, it is possible that there are outliers in the dataset for this study that are prompting the statistically significant result for the Jarque-Bera test. In that case, further processing of the data in this study may be able to produce better results in model development and eliminating the indication of bias. There is also a question of whether this model development process would have been better served by using a statistical software package other than the tools in ArcGIS 10.0. Using ArcGIS was a convenient option due to the spatial nature of several of the attributes that were being considered, but there were several apparent glitches or complications with using these tools that may not have occurred with statistical software that is specifically designed for that purpose. There were a number of instances when the ArcGIS OLS tool would not run due to perceived multicollinearity issues, and it is certainly possible that some amount of predictive value was lost by being unable to include certain variables. For example, the tool would not run when a variable and its squared value were both included in the model specifications. Naturally the values of these attributes would be correlated, but they were not perfectly correlated, and it could add explanatory power 
to include both in the model. Additionally, the OLS tool would often not run if there were binary variables included, and it took a lot of trial and error to determine which would allow the model to run. Based on these issues, as well as the unclear implications of the Jarque-Bera test, this study could potentially benefit from being replicated using another software application.

\section{Applications and future research}

The next step of this study, which will be conducted in the summer of 2013, is to finalize the models that have been produced here and use them to estimate future land values in Yamhill County. Using land use change scenarios that are being developed as part of the SESAME project, the models will be applied to project the value of land in each of the three land use categories - forest, agriculture, residential (Hoyer and Chang 2013). ArcGIS will be used to identify the parcels that are projected to change to a different land use under three different scenarios: high, medium, and low levels of development. The scenarios were heavily influenced by the land use and zoning laws that are in place in Oregon (discussed in the introduction to this paper). Because of Oregon's urban growth boundaries, the areas where future development could potentially occur are limited, and this was reflected in the somewhat low levels of conversion expected. However, changes in land use will occur, and it is valuable to understand the potential economic drivers and implications of land conversion. Since most of the change that is expected in the area will be from either agricultural or forest lands to development (rather than shifts from development), the main outcome of this analysis will be an estimation of the change in market value that could occur under high, medium, and low development scenarios. 
This assessment will indicate whether developing lands in the study area appears to be beneficial in terms of market value alone, as this study did not address the contribution of non-market goods and services to the value of land in Yamhill County. It is important to note that land being used for residential purposes contributes a provisioning ecosystem service in the form of shelter, which should be captured by the values utilized in this study. However, incorporating the impact of ecosystem services such as water quality improvement, provision of wildlife habitat, and aesthetic and recreation benefits would provide a more complete picture of the true value of a given land parcel. These values also vary across the landscape and can be difficult to model, but valuation of ecosystem services is an increasingly prominent area of study. Accounting for the contribution that these natural processes provide is essential to ensuring they are preserved. When nonmarket services are left out of land value, there is little incentive to protect the areas that provide the greatest level of ecological and/or cultural benefits. Even with the relatively low level of land conversion expected, there can be significant implications for ecosystem services if areas of high ecological value are among those converted.

Numerous studies have performed hedonic modeling in order to provide greater understanding of the non-market ecosystem service values that are contributing to land values. Swinton et al. (2007) examined the utility of hedonics in assessing the value of agricultural ecosystem services. Their study suggested that hedonic modeling could reveal ecosystem services values that are contributing to farmland productivity (and thus economic value), such as improved soil quality. Mahan et al. (2000) used hedonic modeling to infer the value contribution of wetland areas to property values in the Portland, Oregon metropolitan area. Their study found that the presence of wetlands has a significant positive impact on property values, and that house values increase 
with proximity to wetland and size of wetland. This type of research is crucial in generating more robust estimates of the contribution that non-market ecosystem services are making to land value and in working toward incorporating these benefits into market prices. It is necessary to have baseline information on the value of environmental attributes in order to identify potential policy and planning activities that can preserve these values (Bastian et al. 2002). Currently, methods for assessing the value of non-market ecosystem services are mostly in development stages, with few widely-accepted approaches. A study by Ma and Swinton (2012) produced a hedonic model for agricultural land valuation that attempts to capture three elements of worth: production, consumption, and asset value. This study found that certain ecosystem service values are being capitalized into property values, particularly those that fall under the category of direct use (such as water resources or forests). However, they noted that other ecosystem services are likely not being accounted for or reflected in land prices, due to lack of awareness, lack of incentive to pay for public goods, and/or low perceived value of these services. As this demonstrates, further efforts are needed to capture the value of non-market ecological benefits. Utilizing hedonic modeling and other revealed preference techniques may provide valuable insight into the contribution of nonmarket goods and services, in order to ensure they are adequately accounted for in planning and management decisions. 


\section{REFERENCES}

Anderson, S.T. and S.E. West. 2006. Open space, residential property values, and spatial context. Regional Science and Urban Economics, 36: 773-789.

Baker, J.P., Hulse, D.W., Gregory, S.V., White, D., Van Sickle, J., Berger, P.A., Dole, D., and N.H. Schumaker. 2004. Alternative futures for the Willamette River Basin, Oregon. Ecological Applications, 14(2): 313-324.

Bastian, C.T., McLeod, D.M., Germino, M.J., Reiners, W.A., and B.J. Blasko. 2002. Environmental amenities and agricultural land values: A hedonic model using geographic information systems data. Ecological Economics, 40: 337-349.

Beach, R.H., Pattanayak, S.K., Yang, J., Murray, B.C., and R.C. Abt. 2005. Econometric studies of non-industrial private forest management: a review and synthesis. Forest Policy and Economics, 7: 261-281.

Brys, G., Hubert, M. and A. Struyf. 2004. A robustification of the Jarque-Bera test of normality. COMPSTAT 2004 Symposium, Section: Robustness.

Cheshire, P. and S. Sheppard. 1995. On the price of land and the value of amenities. Economica, 62(246): 247-267.

"Exclusive Farm Use District - Yamhill County, Oregon." Yamhill County Department of Planning and Development, Zoning Ordinance, p. 402-426. http://www.co.yamhill.or.us/plan/planning/ordinance/zoning_0402_872.pdf

Fotheringham, A.S., Brunsdon, C. and M. Charlton, 2002. Geographically Weighted Regression: The Analysis of Spatially Varying Relationships. Wiley, Chichester, UK.

Freeman, A.M. 1979. Hedonic prices, property values and measuring environmental benefits: A survey of the issues. The Scandinavian Journal of Economics, 81(2): 154-173.

Geoghegan, J., Wainger, L.A., and N.E. Bockstael. 1997. Spatial landscape indices in a hedonic framework: an ecological economics analysis using GIS. Ecological Economics, 23: 251 264.

"Geography of Yamhill County." Yamhill County Website. Accessed online: http://www.co.yamhill.or.us/about/geography.htm

Hayashi, F. Econometrics. 2000. Princeton University Press. Accessed online: http://press.princeton.edu/chapters/s6946.pdf

Hoyer, W. and H. Chang. 2013. Development of Future Land Cover Scenarios in the Tualatin and Yamhill Basins, Oregon, U.S.A. (April 5, 2013 draft). Document of Spatial Ecosystem Services Analysis, Modeling, and Evaluation (SESAME) project. 
Interpreting OLS Result. ArcGIS Desktop 9.3 Help. 2009. Accessed online: shttp://webhelp.esri.com/arcgiSDEsktop/9.3/index.cfm?TopicName=Interpreting_OLS_ results

Lochl, M. and K.W. Axhausen. 2010. Modeling hedonic residential rents for land use and transport simulation while considering spatial effects. The Journal of Transport and Land Use, 3:2 (39-63).

Ma, S. and S.M. Swinton. 2011. Valuation of ecosystem services from rural landscapes using agricultural land prices. Ecological Economics, 70: 1649-1659.

Mahan, B.L., Polasky, S. and R.M. Adams. 2000. Valuing urban wetlands: A property price approach. Land Economics, 76(1): 100-113.

Milon, J.W., Gressel, J., and D. Mulkey. 1984. Hedonic amenity valuation and function form specification. Land Economics, 60(4): 378-387.

Nelson, A.C. and T. Moore. 1993. Assessing urban growth management: The case of Portland, Oregon, the USA's largest urban growth boundary. Land Use Policy, October, 293-302.

Oregon Department of Land Conservation and Development 2011. Ballot Measures 37(2004) and 49 (2007): Outcomes and Effects. Accessed online: http://www.oregon.gov/LCD/docs/publications/m49_2011-01-31.pdf

Sander, H.A. and R.G. Haight. 2012. Estimating the economic value of cultural ecosystem services in an urbanizing area using hedonic pricing. Journal of Environmental Management, 113: 194-205.

Shonkwiler, J.S. and J.E. Reynolds. 1986. A note on the use of hedonic price models in the analysis of land prices at the urban fringe. Land Economics, 62:1 (58-63).

Snyder, S.A., Kilgore, M.A., Hudson, R. and J. Donnay. 2007. Determinants of forest land prices in Northern Minnesota: A hedonic pricing approach. Forest Science, 53(1): 25-36.

Srour, I.M., Kockelman, K.M., and T.P. Dunn. 2002. Accessibility indices: Connection to residential land prices and location choices. Transportation Research Record 1805, Paper No. 02-2589.

Sunding, D.L. and A.M. Swoboda. 2010. Hedonic analysis with locally weighted regression: An application to the shadow cost of housing regulation in Southern California. Regional Science and Urban Economics, 40: 550-573.

Swinton, S.M., Lupi, F., Robertson, G.P. and S.K. Hamilton. 2007. Ecosystem services and agriculture: Cultivating agricultural systems for diverse benefits. Ecological Economics, 64: $245-252$. 
What they don't tell you about regression analysis. 2013. ArcGIS Help 10.1. Accessed online: http://resources.arcgis.com/en/help/main/10.1/index.html\#//005p00000053000000

"Yamhill County." 2013. Oregon Blue Book. Accessed online: http://bluebook.state.or.us/local/counties/counties36.htm

"Yamhill County Comprehensive Land Use Plan." 1996. Yamhill County website. http://www.co.yamhill.or.us/plan/planning/ordinance/comp plan 01.asp?\#RURAL\%20 REA

"Yamhill County_-Information for Partners and Participants." United States Department of Agriculture Natural Resources Conservation Service. Online: http://www.or.nrcs.usda.gov/whats available/lower willamette/yamhill.html

Yoo, S., Im, J., and J.E. Wagner. 2012. Variable selection for hedonic model using machine learning approaches: A case study in Onondaga County, NY. Landscape and Urban Planning, 107(3): 293-306. 